\title{
A STUDY OF FEMINIST IDEAS IN THE POETRY OF SOUAD AL- SABAH
}

\author{
Zahra Farzizadeh $^{1}$ \\ Fatemeh Yusefi ${ }^{2}$ \\ Shahriar Giti ${ }^{3}$
}

\begin{abstract}
Feminism literally means
patriarchy, patriarchy, women's "women's liberation"," womanism " dependency, women's subordination, which is itself divided into different ways. Feminism has sometimes been and lack of public presence in Souad alSabah 's poetry.
\end{abstract} interpreted as organized movements for women's rights and sometimes for the theory that believes in equality between

Keywords: Feminism, Patriarchy, Patriarchy, Equality, Women's Rights, Souad al-Sabah.

men and women in political, economic, social and legal terms. With the spread of the feminist movement, much work was written on women, and all of them had a fixed principle that was to remove the inferiority and inequalities that had been permitted to women throughout history. With the spread of such works, feminist literature emerged. And many poets and writers have created works in this regard. Kuwaiti poet Souad al-Sabah is one of these poets. In this study, we have tried to look at feminism and its implications in terms of feminism, including

\section{Introduction}

\section{The Literal Definition of Feminism}

The word feminism is derived from the Feminine root, which in French and German is equivalent to Feminine, which means woman or female, which is derived from the Latin feminine. (Rudgar, 2009). In Persian, equivalent to such as ' Feminine look ', ' Feminine tendency ', 'women's liberationism' and 'Feminism' have been suggested for the word." (Zibayinejad, 2003).

\footnotetext{
${ }^{1}$ M.A Student, Department of Arabic Language and Literature, University of Mohaghegh Ardabili, Iran. Email: zahrafarzizadeh1374@gmail.com.

$2 \mathrm{PhD}$ student, Department of Arabic Language and Literature, Ferdowsi University of Mashhad.Iran. Email: Fyusefi9@ gmail.com

${ }^{3}$ Assistant Professor, Department of Arabic Language and Literature, University of Mohaghegh Ardabili, Iran. Email: sh_giti@uma.ac.ir
} 
"The word feminism was first

written in 1871 in a French-language medical text to describe the kind of growth retardation the sexuality of male patients who are thought to suffer from the feminine characteristics of finding their bodies. A year later a French antifeminist writer used the word to refer to women who behave masculine. Although in the medical culture the meaning of feminism was to characterize men as feminine, in the political term the term was first used to explain the masculine characteristics of finding women. Until the sixties and seventies, the term was not used to refer to women's organizations and had limited application to specific issues and groups. It is only recently that the use of the term has become widespread and widely used by all groups concerned with the issue of women's rights. (Friedman, 2002)

\section{Definition of Feminism}

Feminism is sometimes referred to as organized movements for women's rights and sometimes to the theory that believes in equality between men and women in political, economic, social and legal terms (Rutledge, 2009). There are various definitions of feminism that we briefly refer to. "Feminism, or the defense of women's rights, is a social movement whose aim is to provide men with an equal footing in the cultural, social and economic contexts of women." (Sarukhani, 1996). "A religion that promotes the promotion of women's rights and roles in society." (Michel, 1999) Jane Flex also argues that feminism is a theory that analyzes gender relations. (Moshirzadeh, 2002) It seems to me that among these definitions, the definition given by Mr Bagher Sarokhani in his book of feminism is more comprehensive.

\section{Backgrounds and Factors of} Feminism

Looking at the historical background of feminism, it may be possible to infer some of the differences in the interpretation of the term. "Feminism was originally the social movement of women in France and other western countries against the inequalities of legal, economic, political and nonequilibrium protests in modern reform. Legal reform since the 1890s has recognized the right of men to vote, and this has further highlighted the discrimination between men and women. Thus, attention to legal and political reforms is the highlight of feminism and 
can therefore be regarded as a women's rights advocacy movement. The second wave of feminism, which began in the 1960s with the development of ideological ideas to analyze the causes of women's subjugation and the delineation of feminist ideals, began in the seventies to discuss the topic of feminism in the humanities, and in the eighties, turned to feminist epistemology. He focused on general criticism of philosophy, epistemology and knowledge production. Accordingly, the second wave was formed on the basis of specific scientific theories." (Rutledge, 2003) From the mid-1990s to the 1970 s, the grounds for the emergence of the third wave formed. That was largely due to developments in the capitalist system, the emergence of the modern postal outlook, and the resulting radical and unilateralism of the wave of the latter, so that Today, many are advocates of the second wave's tendencies to criticize it. Several important features distinguish the third wave from the second wave, the most important being the emphasis on differences, so that some have attempted to address the dilemma of difference in the main characteristic of the third wave. And. The issue of difference, both from different groups of women, including skin color, American women, and all from reproductive (presented by: 1) an in-depth, unambiguous image of "Woman," 2 comprehensive explanations of patriarchal temporal and temporal contexts, 3 universal strategies, invalidate them, and each of them "To present the theory of the feminist unit is doomed to failure, and it has been put forward for a number of groups and guilds and for a single feminist project in existence" (Same: 18).

In the last centuries, feminists have stood up to defend women's rights to help improve the status of women by marginalizing women, by explaining the factors and forces affecting the phenomenon. And poetry is a means by which poets seek to express their ideas. Among the poets, women have a particular attitude to their sexuality and reflect on female-centered ideas, including Kuwaiti poetry, which is a tribute to Kuwaiti poetry. Voting in the book (Take Me to the Solar Frontier) has been photographed. The purpose of this study is to examine and analyze the feminist notions in the poetry of this poem in a descriptive-analytical way.

\section{The life and poetry of Souad al-Sabah}


Souad Mohammed al-Sabah came to Kuwait in 1942 in Kuwait. He is a poet and a descendant of Amir Mohammed al-Sabah, King of Kuwait. After receiving a $\mathrm{Ph} . \mathrm{D}$. in economics and political science at the University of Sari, Gloucester, USA, despite his academic background, he never took a material look at life but saw it. The first is the purely intellectual, cultural, and emotional world and human being (Ragheb, 1993). In his poem one can seek to restore human and women's rights, restore identity A woman defends the fate of a woman in a corporation Versus Love and Humanity (Madani, 2006; al-Sabah, 2012: Introduction); more prosperity has been attempted to ignore the essence of man or Come closer to being feminine. Once the poet lived there, more theocracy and the barbaric system in place, more people in cities and villages, Yazd, ignorance, Diseases and adversities affected social conditions. (Al-Mushoush, 2011) Extensive insecurity, disregard for citizenship, presence and interference of all aliens in the community. State affairs, a humiliating look at poor sexuality, a monopoly of suffrage for men, all of these factors that underlie the great revolutionary thought of the poet
(Hussam, 2003) Souad al-Sabah 's poetry as an effective means of protesting; Incorrect traditions apply the inequalities of the patriarchal system to the enlightenment of women's rights as a basis for expressing their poets' feminine abilities And finally to achieve the most important of Ashi's desires in removing inequalities (Mohammadi \& Maleki, 2017).

\section{Patriarchy}

Patriarchy is One of the most influential, and perhaps most important factors in women's self-esteem in all societies. Patriarchy is a term in which the Greeks mean the sovereignty of the Father.

At the academic level, patriarchy was the first theoretical breakthrough among anthropologists to describe this term in describing any society in which a paternalistic "father" assumed absolute dominance. Members, including the younger Tarah and the disobedient subordinates, were being used. Among feminists, these terms are applied not only to a particular type of community but also to the concept that masculine domination the core of the organization has been all societies. In addition to being aware of each other's 
male and female relationships and their family relationships, it offers ideas, values, politics, culture, concepts; Social and political power is such that military, industry, technology, universities, science, political positions, commerce, and in particular all power corridors in society, including The police force - all in the hands of the men. The removal of women from social authority is a universal phenomenon and, in all societies, especially in the Middle East, men's social and domestic activities and activities related to the home and $\mathrm{A}$ family is one of those women. In feminist groups, radicals know their oppressors as men (Legit, 2016) and (Payne, 2015)

For one hundred years on this side / You are like a marine creature / In my memories / I want you to emigrate but not to travel / Travel tickets Do you / I close your luggage to open the door again / I ask the police to arrest you / but arrest me (al-Sabah, 1999)

In this piece of my poem, there is a strong sense of entitlement, as well as a defense of women's rights, a dominant context, and a commitment to women's limitation, inequality of social rights, the tradition of customary beliefs and so on has risen.
This is my country that castrates a woman / Hides the sun at sunrise / As a family / woman security Allegedly, she kills him / or if he thought / or wrote / or fell in love / to become the family's fiancé (Same: 100)

Souad al-Sabah seeks to take over the role of man of the society by taking pictures of women in Kuwait to achieve this goal beyond matters such as defense; Emphasizes the right to libertarianism, the normalization of, and resistance to, the tradition of patriarchal society. She is of particular importance for the key role played by women in the family and in society, so that in her poetic form she is in front of the landscape. He looks at the sunrise as "sunrise". By defending the political and social status of Kuwaiti women, she advocates for the rights of women in their own time. A woman who had no right to speak, not to think or to write, and to have the right to fall in love ... in the face of the expression of feminine emotions in Bobby Love is to be killed, freedom and democracy is truly realized because a woman lives in a patriarchal society that does not even have the right to speak in society because This is considered an ugly and unpleasant army. In the aftermath, such a society will have 
a love of more grandeur and greater sighs (al-Sabah, 1991).

Souad al-Sabah seeks to take over the role of man of the society by taking pictures of women in Kuwait to achieve this goal beyond matters such as defense; Emphasizes the right to libertarianism, the normalization of, and resistance to, the tradition of patriarchal society. She is of particular importance for the key role played by women in the family and in society, so that in her poetic form she is in front of the landscape. He looks at the sunrise as "sunrise". By defending the political and social status of Kuwaiti women, she advocates for the rights of women in their own time. A woman who had no right to speak, not to think or to write, and to have the right to fall in love ... in the face of the expression of feminine emotions in Bobby Love is to be killed, freedom and democracy is truly realized because a woman lives in a patriarchal society that does not even have the right to speak in society because This is considered an ugly and unpleasant army. In the aftermath, such a society will have a love of more grandeur and greater sighs (al-Sabah, 1991).

What do women want in our country? / Do they want to be cranky / or are they barbecue? He is ready to be a joiner / They want him to be a small donor / These are ten ten-fold commands to preserve family records (al-Sabah, 1999)

The female subject in poetry has an important place in poetry. The equality of rights between women and men has been raised. (al-Sabah, 2012)

Therefore, the great volume of her poetry is about women and the limitations of the oppression that has gone on in Arab society ever since. With her poems she reflected on the situation of women in her country.

Criticizes it in a broken section; sorry I want to apologize / I won't wear my own nails / Always in front of the caravan / I will get in the way / And Always / The Murdered or Remain Killer (al-Sabah, 1999)

Souad wants to come out of the patriarchal arsenal of self-determination; he wants independence of selfdetermination.

\section{Patriarchy}

Patriarchy is a concept that speaks of gender inequality for the benefit of men and for the dominance of men over women. According to RickWilford, patriarchy means what it 
means. It is inevitable that they will be dominated by women and will use every means, whether fair or unfavorable, to achieve this end (Wilford, 1996). The term originally used by feminists has been used in social sciences. Patriarchy has a number of characteristics, including the exercise of the authority of the great man, all at home in society, and the self-denial of man demonstrates superiority over women. But in the feminist literature, the concept of title, which is of political importance, has wide application. The term "new application" refers to ideas and practices that are most closely related. Sexual offenses go beyond the most general economic and ideological factors. The patriarchy has been applied in a sense that - not only has the power of all the men of power been exercised, but also has the power of legitimacy of the sovereignty of the power of legitimacy. This power was as natural, normal, just as equitable (Payne, 2015).

- Out of this hundred years of life / And you are trying to make a living for me / Like your private apartment / Lying on your pillows / Whenever you want, / Whenever you wanted, you would have clothes in your wardrobe / whenever you wanted to prepare coffee (al-Sabah, 1999)

In appearance, it was transformed into a special object that had no voluntary self-possession and was owned by men and thus represented the patriarchal monarchy in traditional societies.

This is my country, which has eaten its wives / has been fortunate / has sunburned underpants / this country is waqi, which is thought to confiscate / and its women in Marrying a bed like a camel / Lying to the moons / Taking care of its worshipers / My country coming out of a broken flower / And not liking musk Does not see in dream except sex and bed (Same: 102)

For Souad al-Sabah, men are accused of being self-centered in pursuing their own desires and desires, and in their minds, desires, and women's identities, desires and desires, this man is born of a patriarchal attitude in traditional societies. At the throne, he is pursuing a lover of materialistic sex accounts. "Do not look at her physical beauty alone with her materialistic and exclusive look, because from such a viewpoint, such a view of the woman as a speculative person is a lover of peace." It is a kind of self-respect - to starve a 
woman as a human being" (Hussein alAnif, 2011).

\section{Women's Dependency}

The fate of a traditional, societal society is the cause of marriage. From traditional children to morality, traditionalism, desire for attributes such as independence, rationality, the will and freedom of choice for women, in exchange for domination (others), dependence on others, dependence on women. Emotionally, physically, peacefully, and inducing them to be a part of the humiliation of the critics. Girls are humiliated and humiliated because they know nothing about life. Because they do not know how they can find their livelihoods. ( $\mathrm{Du}$ Beauvoir, 2000)

One must fight for freedom; one for freedom, equality and social justice for all, freedom of expression, selffreedom. Women should be able to achieve their self-control-their-life goals (Legit, 2016.

Unsupportable / Unsupportable / Unsupportable / Unsupported / Unlimited / Unlimited / Unlimited Finishes / When Fingers Graduate (alSabah, 1999)
The most destructive cultural position for women to live in is a situation that emphasizes self-esteem without the need for a self-reliant relationship (Pinkolaastes, 2016)

From their point of view, it is possible for men to provide themselves with a greater ability than men to see women should be able to change their conditions for self-esteem. Self-esteem, family, race, culture, culture (Same: 127)

Hours, bells / And human weights, comes with a hundred / Alps windswept helmets / Weberf, selfimmolation-burn / veto / Angle ... Width / Width ... Width / Angle ... Angle / Width ... Correct ... / Clock, Ringing / And what about superlative lenses / magnificent lobsters / what a bunch of days in the city (al-Sabah, 1999)

In terms of women, they should be fully self-sufficient. If they can freely equip their love, their hard-earned money will have to be truly selfcentered. They will, at their own discretion, have the luxury of easy access to the nonprofit.

- My problem has nothing to do with my heart / But it is my memory ... / This memory you have been forced to occupy / For a hundred years ... / Without my consent ... / And Without my will / 
And without a rental agreement with you. (al-Sabah, 1999)

Souad al-Sabah has rebelled against the injustices in patriarchal society and has taken a critical look at the issue. He wants self-determination that is in line with feminists.

\section{Women's subordination}

For feminists, women have been subjected to oppression and discrimination except for a brief moment in human history's long history of subjugation in all cultures, nations, and lands. They have been oppressed and dominated by patriarchy. Monocracy is a system of oppression and discrimination against women that is practiced and promoted in all walks of life, including personal relationships, sexual behaviors and other social, cultural, and other aspects. All oppression and discrimination in economic, social, and cultural systems is designed and reinforced by the patriarchal system, and the system is coordinated between different systems to maintain the dominance of sex or class over sex or female class. (Bostan, 2003) To them patriarchy is transhistorical (Robot, 2006) and does not belong to a historical period or culture. Men and women throughout history and through their gender are always and always inferior to men and some forms of this subordination can be identified in terms of oppression and discrimination (Rodger, 2009).

- This country has closed its sky ... / And its women have mummy ... / Face is in it / Sound is in it / Thought is in it / Poetry is in it / Love is in it / And also Green Moon and Blue Letters (alSabah, 1999)

The woman in the poet's society has been neglected and her rights have been violated. Souad al-Sabah has criticized the situation of oppressed women in a very blatant way and is not satisfied with their situation in the royal state of Kuwait. And elsewhere he has a critical look at women's inferiority:

Little dictator / Whatever you do, I will not blame you / Whatever you make me feel / Whatever your thoughts crush me ... / Whatever evil you do / You were never strong / But my weakness made me / You were never great / But I ... / With my love I lifted you up to heaven (Same: 94)

In the poet's view, women are not only passive, they can also be active and influential. Men's greatness and greatness is because women make 
themselves weaker and smaller so that men can attain high status.

What do the sleepy, lazy, and unaware cities want from me ... / My wounded ... fragile ... warrior? / If my mind wants it, / Wouldn't I be lucky to be wise ... / What can a woman do in her rain? What does a woman do in her rivers? / How can one plant flowers in this dry land? (Same: 106)

Poetry is a reflection of his own life, a reflection of the anguish and shouting of the realities of a patriarchal society that embody the experience of many women in his land. The brazen, oppressive spirit of prosperity does not reflect false beliefs and traditions. Weber is committed to defending the rights of all women. Women who have been deprived of their full humanity.

\section{Absence in the public domain}

The history of Western culture shows that women are inappropriate in the public arena, a history that is rooted and common. For Aristotle there was no ambiguity about the exclusion of women from the activities of the city administration. In her view, although women play a vital role in the life and survival of the city, they do not have the time to engage in politics despite responsibilities such as feeding their children and doing housework. Plato, who, in a revolutionary theory of his contemporaries, believed that the most capable upper-class women could take part in political rule, established in his book Laws a Tradition in which Politics and Women Fail. (Mosafa, 1995)

- For over a hundred years ... / I'm trying to break the white plaster circle / where you've imprisoned me ... / And hiding the keys in your pocket ... / Out of a hundred This year ... / I try to persuade you to respect human rights / And the rights of women ... / But you ... like all the men of the tribe ... / You insisted on keeping your possessions. .. / The sunsets that do not set in the sun ... / And their red flags / On my memory on the frostbite (al-Sabah, 1999)

Souad al-Sabah depicts the injustices and patriarchal oppressions that take place at the heart of the family and seeks to defend women's rights of its time. This is in line with the liberal feminist notion that women are confined to the private, home, and oppressive realms of women. Of humility and humility.

you who sit on my bed like a king / Even if it is for a day, save me from 
Release Your Dominion / Every Street I Walk ... Your Name Is Closed On / Walking into Every House ... Lonely Behind Me / Sheltering in Every Public Park It closes ... / All the boutiques that I buy my clothes / Don't sell to me / Before I talk to you / Get out of my skin / To continue my life naturally. ... / and breathe naturally (Same: 62)

In this poem, Souad al-Sabah wants to advocate for women's rights and invites them to seek freedom and a cultural revolution. And he openly protests against ignoring the rights of nations. Like feminists, she believes that "the only way to combat this discrimination and to see it is to reform the social, political and cultural structures of society.

\section{Conclusion}

Souad al-Sabah uses poetry as an effective means of protesting against false traditions, inequalities of the patriarchal system, to enlighten women's rights by laying the groundwork for expressing her feminine tendencies and poetic taste, and ultimately achieving her most important desire, namely Removes inequalities. Criticizes anti-patriarchal traditions and ancient beliefs and criticizes ancient beliefs and practices and calls on the contemporary woman to play an active role in the public arena, from an active subject to a subject. Become an actor in order to regain and maintain her position as a woman in the system of existence.

\section{References}

Bostan (Najafi), Hussein, (2003), Inequality of sex and sexuality from the perspective of Islam and feminism, Qom, Institute of Domain and University

Payne, Michael, (2015), Critical Thinking and Culture, Translated by Yazdanjo Message, Fifth Edition, Tehran, Center Publishing

Pinkolastes, Clarissa, (2016), Women Running with Wolves; Myths and Stories about the Ancient Pattern of the Wild Woman, Translated by Simin Movahed, Shidab Publishing

Hesam, Farahnaz, (2003), Government and Social Forces in the Age of Pahlavi I, Tehran, Islamic Revolution Documentation Center Publications 
De Beauvoir, Simon, (2000), Second

Gender, Translated by Qassem Sanawi,

Second Edition, Tehran, Toos

Publishing

Robotam, Sheila, (2006), Women in

Struggle: Feminism and Social Action,

Translated by Heshmatollah Sabaghi,

Tehran, Shiraz Research Publishing

Rothlage, (2009), Feminism and Feminist Knowledge, Translated by:

Behrouz Jandaghi and Abbas Yazdani,

Second Edition, Qom, Office of

Women's Studies and Research

Rodger, Narges, (2015), Feminism;

History, Theories, Trends, Criticism,

Second Edition, Tehran, Office of

Women's Studies and Research

- The Beauty of Race, Mohammad Reza (2003), Feminism and Feminist Knowledge, Qom, Office of Women's

Studies and Research

Sarokhani, Bagher, (1996), Introduction to Social Sciences Encyclopedia, Tehran, Kayhan
al-Sabah, Souad, (2012), Love Poems,

Translated by Amena Jahangir Esfahani,

Tehran, Academic Jihad Publications

(1999). Take Me to the

Border of the Sun, Translated by Hassan

Faramarzi, Tehran,

Friedman, Jane, (2002), Feminism, Translated by Firoozeh Mohajer, Tehran, Ashian

Legit, Marilyn, (2016), Women in Their Days, Nilofermahdian Translation, Fourth Edition, Tehran, Ney Publishing

- Mohammadi, Majid and Afsaneh,

Maleki, (2017), "The Semantic Aesthetics of Poems by Souad al-Sabah and Jaleh Farahani with Female Focus and Female Emotions", Ninth Year, Quarterly Scientific Research Journal, No. 33, pp. 77-95

Madani, Nasrin, (2006), In the Alley of Innocence: A Comparative Critique of Forough Farrokhzad and Ghadam alSassan Contemporary Arab Poet, Tehran, Cheshme

Moshirzadeh, Homeyra (2002), From Movement to Social Theory: The 


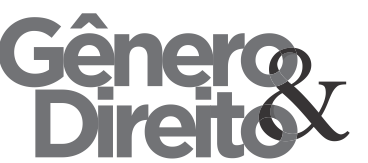

Periódico do Núcleo de Estudos e Pesquisas sobre Gênero e Direito

Centro de Ciências Jurídicas - Universidade Federal da Paraíba

V. 8 - $\mathrm{N}^{\circ} 05$ - Ano 2019

ISSN | 2179-7137 | http://periodicos.ufpb.br/ojs2/index.php/ged/index
History of Two Centuries of Feminism,

Tehran, Shiraz Research Journal

- Masafa, Nasrin, (1995), "Report on

Feminist Interpretation and Political Theory", Journal of Foreign Policy, Issue

2, Summer 1995

Michel, Andre, (1999), Feminism, Women's Social Movement, Translated by Homa Zanjani Zadeh, Second Edition, Mashhad, Nika Publishing.

Wilford, Rick, (1996), "Feminism", An Introduction to Political Ideologies, Translated by Mohammed Qaeda, Tehran, Nashrum Center.

Hussein al-Afiyev, Fatemeh, (2011), Contemporary al-Sher al-Arabi: Thakul al-Malaiki and Sa'ad al-Sabah and Nabil al-Khattib, al-Jordanian al-Qa'id alQa'idah: al-Atb al-Hadithi al-Lanzi'ir.

Ragheb, Nabil, (1993), Azzaf Ali Jutar al-Maduqi; On the Poetry of Sa'ad alSabbah.

Raouf, Ezat, (1995), al-Marim al-Siyasi, al-Wali al-Ameriya, al-Alimi al-Laflari al-Islami.
Al-Moush, Salem, (2011), al-Adab alArabi al-Hadith, al-Thaba'a al-Thani, Beirut: Dar al-Nizah al-Arabi 